\title{
Management of ballistic soft tissue injuries: a review
}

\author{
Dr Smita Goorah ${ }^{1}$, Dr Sandip Hindocha ${ }^{2}$ \\ ${ }^{l}$ (Department of Medicine, University of Mauritius, Mauritius) \\ ${ }^{2}$ (Department of Plastic and Reconstructive Surgery, Whiston Teaching Hospital, United Kingdom)
}

\begin{abstract}
Civilian populations are increasingly vulnerable to ballistic injuries resulting from firearms or from bomb blasts. Injuries of the extremities are most common with firearm-related violence and wounds of greater complexity are seen with explosive devices. Initial management is targeted to dealing with life-threatening conditions and stabilizing the patient followed by subsequent care in a well-equipped setting. In this paper, we review and discuss various management modalities specifically for ballistic soft tissue injuries which include conservative or surgical management, appropriate wound care, use of antibiotics and definitive management and reconstruction of soft tissue injuries. Initial evaluation can usefully classify the ballistic injury into a highrisk or a low-risk category and this influences subsequent management. Low-risk ballistic injuries can benefit from conservative non-surgical management. Experience acquired from the treatment of military ballistic wounds can be used in civilian settings especially in the case of wound debridement and use of antibiotics. Definitive management of soft tissue injuries usually involves the use of flaps for reconstruction.
\end{abstract}

Keywords - ballistic injuries, reconstruction, soft tissue injuries, wound care

\section{INTRODUCTION}

Ballistic injuries in civilian settings appear to be on the rise throughout the world although global statistics are limited by lack of reliable data in many countries. A recent paper [1] estimated that deaths, unrelated to conflicts and military or police action, due to firearms throughout the world were in the range of 196000 to 229000 adjusted to year 2000 population estimates. However, firearm related injuries and deaths currently remain rare in the United Kingdom and Wales. A retrospective study looking at firearm injuries from the Trauma Audit and Research Network database from 1998 to 2007 showed that only $0.53 \%$ of cases were due to firearm injury [2]. Moreover, recent Home Office figures in the United Kingdom revealed that "firearm offences involving any type of injury decreased by seven per cent, from 2,568 in 2009/10 to 2,399 in 2010/11" [3].

Many advances in the understanding and management of ballistic injuries have been made by military surgeons over the past five centuries as the nature of wounds changed with the introduction of new weapons with different capabilities [4]. Increasingly though, it is anticipated that civilian orthopaedic surgeons would be required to be familiar with the management of ballistic injuries especially of gunshot fractures of the extremities [5]. In developing countries with inefficient firearm control, armed robbery and firearm related violence accounted for ballistic injuries in civilian populations. In a study carried out in Nigeria investigating the pattern of civilian gunshot injuries, it was found that the extremities were most affected by such injuries followed by the face and chest [6]. In contrast, recent military action has witnessed an increasing use of improvised explosive devices. The use of vehicular and body armour by soldiers have fortunately led to fewer thoracic and abdominal wounds; however an increased incidence of wounds affecting the head, neck and extremities with more complex wounding patterns have been observed [7]. Hence, surgeons are being required to deal more frequently with gunshot wounds of the extremities and also wounds of greater complexity.

Ballistic injuries commonly occur either from firearms or as a result of blasts from explosive devices. Where firearms are concerned, bullets can be classified as expanding bullets maximising tissue damage or nonexpanding bullets maximising penetration [8]. Bullet or projectile injuries have been usefully classified into "high-energy" or "low-energy" injuries reflecting the degree of tissue damage. The amount of energy transferred at impact with the tissues is influenced by the nature of the tissues; more rigid tissues offer a greater resistance and result in higher energy transfers and hence sustain greater damage, for instance, bone would be more readily injured than a more pliable tissue [9]. The zones of injury have been classified into three zones and this is a useful way of conceptualising tissue damage. Firstly, there is the permanent cavity caused directly by the projectile and this consists of crushed dead and necrotic tissue. Secondly, there is the contusion (or inflammatory) zone consisting of injured tissue adjacent to the permanent cavity. Thirdly, the concussion zone or temporary cavity is due to temporary tissue displacement or stretch [10]. The temporary cavitation is thought 
to be related to the local transfer of energy [11] and the extent of damage to tissues depends both on the nature of the projectile and on the nature of the affected tissues.

The clinical effects of tissue wounding by ballistics can also vary due to the influence of several factors. Identified variables influencing clinical outcomes include the nature of the tissue and its sensitivity to injury, the extent of tissue damage caused by the effects of energy transfer, the extent and nature of bacterial and other microbial contamination and the presence of foreign bodies in the wound. Crucially the quality and timing of medical care are also important factors to be taken into account [12].

This paper's main focus is a review of the management of ballistic soft tissue injuries and excludes visceral and neurological injuries and bone fractures resulting from ballistics.

\section{MATERIALS AND METHODOLOGY}

A literature search was performed of the U.S. National Library of Medicine National Institutes of Health PubMed database using the following search items ballistic _ firearms _ gunshots _ trauma _ injuries wounds _ soft tissue _ management _surgical reconstruction _ outcomes. Inclusion criteria included the following: A) Recent articles (1990 onwards) discussing the management and/or reconstruction of soft tissue injuries caused by ballistics/firearms/shotguns B) Articles discussing human subjects. Articles which were excluded were: A) Articles discussing exclusively visceral, neurological, vascular or bone injuries caused by ballistics, B) Articles discussing wounds not caused by ballistics, C) Articles discussing aspects other than management of soft tissue injuries D) Articles before 1990. 2148 abstract on firearm injuries were reviewed out of which 46 abstracts were selected as they fulfilled the inclusion criteria and full articles were viewed. Articles in a language other than English (French and German) were translated. 34 articles were found to be relevant to this study and are summarized in the result section.

\section{RESULTS}

General guidelines for the management of ballistic soft tissue injuries in the papers reviewed included initial wound cover by a sterile dressing, prophylactic antibiotics if required, wound irrigation, careful excision of non-viable tissues in theatre, surgical exploration if required, wound dressing with saline-soaked gauze and crepe bandage or topical negative pressure wound therapy and delayed wound closure at 4 to 5 days. The results of reviewed articles $[8,11-17]$ are summarized in chronological order in Table 1.

Table 1. Summarizes the different strategies for the initial management of soft tissue injuries

\begin{tabular}{|c|c|}
\hline Authors & Initial management strategies of ballistic soft tissue injuries \\
\hline $\begin{array}{l}\text { Bowyer \& Rossiter, } \\
1997 \text { [11] }\end{array}$ & $\begin{array}{l}\text { - Initial sterile dressing } \\
\text { - } \quad \text { Antibiotic cover } \\
\text { - } \quad \text { Incision and irrigation with copious saline } \\
\text { - } \\
\text { - } \text { Fuscision of damaged subcutaneous fat and fascia and of devitalised } \\
\text { - } \quad \text { Dressing the open wound with fluffed-out gauze } \\
\text { - } \quad \text { Delayed primary suture at } 4 \text { to } 5 \text { days after injury } \\
\text { - } \text { Primary closure to be considered for specific areas: face, neck, scalp, } \\
\text { - } \quad \text { genitalia } \\
\text { - Split-skin grafting for large defects } \\
\text { - } \text { tissues } \\
\text { Non operative management and outpatient treatment for low-energy soft } \\
\text { tissue wounds by wound irrigation, dressing and antibiotic }\end{array}$ \\
\hline Hill et al., 2001 [12] & $\begin{array}{l}\text { - Early management of small fragment, low energy-transfer small ballistic } \\
\text { wounds (especially in civilian settings) without permanent cavitation, } \\
\text { neurosurgical or neurovascular injury and with stable fractures by non- } \\
\text { surgical protocols: early wound irrigation, dressing, early oral antibiotics } \\
\text { and outpatient management } \\
\text { Surgical exploration and management to be considered in the presence of } \\
\text { non-viable tissue }\end{array}$ \\
\hline $\begin{array}{l}\text { Volgas et al., } 2005 \\
{[13]}\end{array}$ & $\begin{array}{l}\text { - Initially ABC sequence of management followed by imaging to identify } \\
\text { any visceral injury and location of path of projectile } \\
\text { - Main management strategy is to assess and excise necrotic or } \\
\text { contaminated tissue } \\
\text { - Wounds with limited soft tissue injury should require excision of entrance } \\
\text { wound and irrigation of bullet track }\end{array}$ \\
\hline
\end{tabular}




\begin{tabular}{|c|c|}
\hline & $\begin{array}{l}\text { - Low risk wound with little bullet fragmentation and without bone } \\
\text { comminution may be minimally excised } \\
\text { - High energy wounds, marked fragmentation of bullet and comminution of } \\
\text { bone require extensive debridement } \\
\text { - } \quad \text { Retained bullet fragments may be left in situ unless located in areas which } \\
\text { cause pain. The latter may be removed electively } \\
\text { - All wounds recommended to left open to close by second intention } \\
\text { - For prevention of infection, high risk wounds are treated by triple } \\
\text { antibiotics until } 72 \text { hours after wound closure and tetanus antitoxin if } \\
\text { required. Low risk wounds may not require antibiotics or may require only } \\
\text { a short course only }\end{array}$ \\
\hline $\begin{array}{llll}\text { Lichte et } & \text { al., } & 2010 \\
{[14]} & & & \end{array}$ & $\begin{array}{l}\text { - General removal of bullet in all cases is not recommended and it can be } \\
\text { left in situ if difficult to retrieve } \\
\text { Low energy bullets require superficial debridement, irrigation, sterile } \\
\text { dressing, healing by secondary intention; antibiotics may or may not be } \\
\text { required. } \\
\text { - High energy injuries are usually associated with severe soft tissue damage } \\
\text { and require aggressive debridement, second look surgeries, excision of } \\
\text { wound margins and wound track as well as removal of foreign material } \\
\text { - } \quad \text { Healthy tissue should not be unduly excised } \\
\text { - } \quad \text { High energy wounds may not require antibiotics } \\
\text { injury and extensive soft tissue injury require intravenous antibiotics with } \\
\text { duration of antibiotics depending on type of injury }\end{array}$ \\
\hline $\begin{array}{l}\text { Eardley et al., } 2011 \\
{[15]}\end{array}$ & $\begin{array}{l}\text { - Initially wound cover with a sterile dressing and stabilization of fractures } \\
\text { as required followed by a single dose of antibiotics if surgical intervention } \\
\text { not possible within } 4 \text { hours } \\
\text { - Assessment of injuries to determine whether conservative treatment (for } \\
\text { selected soft tissue injuries only) or surgical treatment is appropriate. } \\
\text { - A short course of narrow spectrum intravenous antibiotics to be } \\
\text { commenced within } 3 \text { h of injury } \\
\text { - Routine gram-negative cover for all wounds not useful } \\
\text { - Tetanus immunization as required } \\
\text { - Debridement with wound track excision, compartment decompression and } \\
\text { removal of all devitalized tissue, debris and ballistic fragments within } \\
\text { reach with extension of wound beyond the zone of injury for } \\
\text { comprehensive assessment, extremity fractures to be stabilized } \\
\text { All wounds to be left open and dressed with saline-soaked gauze and crepe } \\
\text { bandage or topical negative pressure wound therapy (TNPWT) if } \\
\text { available. } \\
\text { Delayed primary closure at 4-5 days }\end{array}$ \\
\hline $\begin{array}{l}\text { Guthrie et al., } 2011 \\
{[16]} \\
\text { on behalf of the Limb } \\
\text { Trauma and Wounds } \\
\text { Working Groups }\end{array}$ & $\begin{array}{l}\text { - } \begin{array}{l}\text { Consensus recommendations for initial extremity war wound debridement } \\
\text { are described }\end{array} \\
\text { - Irrigation and early wound debridement to be performed in operating } \\
\text { theatre } \\
\text { - Irrigation with warm sterile saline delivered via a low pressure system } \\
\text { preferred } \\
\text { - Careful debridement limited to non-viable skin and macroscopically } \\
\text { damaged fat and fascia only } \\
\text { - Fasciotomies of muscle compartments to be performed as required } \\
\text { - } \quad \text { Primary vascular reconstruction as required at initial debridement but } \\
\text { primary reconstruction of tendons and nerves not recommended at that } \\
\text { - } \quad \text { Sterile gauze and topical negative pressure to be used as wound dressings } \\
\text { - Delayed primary closure advisable at } 5 \text { days } \\
\text { Small superficial wounds require cleansing and irrigation with normal } \\
\text { saline and can be left to heal by secondary intention }\end{array}$ \\
\hline $\begin{array}{l}\text { Hospenthal et } \quad \text { al., } \\
2011[17]\end{array}$ & $\begin{array}{l}\text { - Systemic antimicrobials to be administered as soon as possible after injury } \\
\text { to prevent early infectious complications caused by common bacterial } \\
\text { flora } \\
\text { - Post injury antimicrobials should be given ideally within } 3 \text { hours of injury. } \\
\text { - Extremity injuries involving skin, soft tissue, and/or bone require 1-3 days }\end{array}$ \\
\hline
\end{tabular}




\begin{tabular}{|c|c|}
\hline & $\begin{array}{l}\text { of cefazolin } 2 \mathrm{~g} \text { IV every } 6 \text { hours to } 8 \text { hours } \\
\text { - } \quad \text { Additional gram-negative coverage not felt to be beneficial } \\
\text { - Tetanus prophylaxis to be given as required }\end{array}$ \\
\hline Bruner et al., 2011 [8] & $\begin{array}{l}\text { - } \quad \text { ATLS protocol used initially followed by rapid transfer to a suitable } \\
\text { hospital facility } \\
\text { - Small isolated wounds to skin, subcutaneous tissue and muscle require } \\
\text { - } \quad \text { Himple irrigation and debridement } \\
\text { procedures } \\
\text { - } \quad \text { Direct closure of wounds not advised } \\
\text { - Assessment of intracompartmental pressure for compartment syndrome in } \\
\text { - } \quad \text { Antibiotics required for ballistic injuries associated with fractures, large } \\
\text { soft tissue injury or for shotgun injuries }\end{array}$ \\
\hline
\end{tabular}

Following initial wound care, the next step in the subsequent management of soft tissue injuries usually involves definitive reconstruction. Different strategies used for the reconstruction of soft tissue injuries were reviewed regionally. The results of reviewed articles [18-43] are summarized in Table 2.

Table 2. Summarizes the different strategies for the subsequent management and reconstruction of soft tissue injuries regionally

\begin{tabular}{|c|c|c|}
\hline Region & Authors & $\begin{array}{l}\text { Subsequent management strategies and reconstruction of } \\
\text { ballistic soft tissue injuries }\end{array}$ \\
\hline \multirow[t]{12}{*}{$\begin{array}{l}\text { Head and neck } \\
\text { region }\end{array}$} & $\begin{array}{l}\text { Gruss et al., } \\
1991[18]\end{array}$ & $\begin{array}{l}\text { - } \quad \text { Early definitive bone and soft tissue reconstruction } \\
\text { - A combination of flaps used for soft tissue reconstruction e.g. } \\
\text { free vascularized omental flaps }\end{array}$ \\
\hline & $\begin{array}{l}\text { Shuker, } 1994 \\
{[19]}\end{array}$ & $\begin{array}{ll}\text { - } & \text { Tissue traction technique used successfully in } 20 \text { patients with } \\
\text { soft tissue facial disfigurement }\end{array}$ \\
\hline & $\begin{array}{l}\text { Siberchicot et } \\
\text { al., } 1998[20]\end{array}$ & 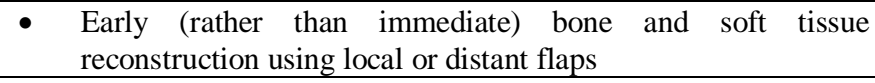 \\
\hline & $\begin{array}{lr}\text { Motamedi } & \& \\
\text { Behnia, } & 1999 \\
{[21]} & \\
\end{array}$ & $\begin{array}{l}\text { - Use of regional flaps to treat facial soft tissue defects followed } \\
\text { by revisions }\end{array}$ \\
\hline & $\begin{array}{l}\text { Hollier et al., } \\
2001[22]\end{array}$ & - $\quad$ Early bone and soft tissue reconstruction \\
\hline & $\begin{array}{l}\text { Safak \& Akürek, } \\
2001[23]\end{array}$ & $\begin{array}{l}\text { One stage reconstruction of cheek defect using free latissimus } \\
\text { dorsi musculocutaneous flap with good result }\end{array}$ \\
\hline & $\begin{array}{l}\text { Motamedi, } 2003 \\
{[24]}\end{array}$ & $\begin{array}{ll}\text { Early definitive simultaneous treatment of maxillofacial hard } \\
\text { and soft tissues }\end{array}$ \\
\hline & $\begin{array}{l}\text { Futran et al, } \\
2005[25]\end{array}$ & $\begin{array}{l}\text { - Use of free tissue transfer techniques for simultaneous } \\
\text { reconstruction of the bony framework and overlying soft } \\
\text { tissues followed by secondary procedures to optimise } \\
\text { aesthetics }\end{array}$ \\
\hline & $\begin{array}{lr}\text { Doctor } & \& \\
\text { Farwell, } & 2007 \\
{[26]} & \\
\end{array}$ & $\begin{array}{l}\text { - } \begin{array}{l}\text { Early definitive reconstruction of bone and soft tissue deficits } \\
\text { with vascularized flaps as treatment of choice }\end{array}\end{array}$ \\
\hline & $\begin{array}{l}\text { Kaufman et al., } \\
2009[27]\end{array}$ & $\begin{array}{l}\text { - Immediate definitive reconstruction (within } 24 \text { to } 48 \text { hours) } \\
\text { - } \quad \text { Initial skeletal fixation } \\
\text { - } \quad \text { Free flap transfer (using distant free flap transfers) consisting } \\
\text { - } \quad \text { of fasciocutaneous flaps or osteocutaneous flaps } \\
\text { Secondary revisions to improve function and aesthetics }\end{array}$ \\
\hline & $\begin{array}{l}\text { Danino et al., } \\
2009[28]\end{array}$ & $\begin{array}{l}\text { - Early definitive reconstruction of soft tissue compartments of } \\
\text { the face (within first } 10 \text { days) with single free composite } \\
\text { latissimus dorsi musculocutaneous flap with multiple skin } \\
\text { islands after debridement and bony stabilization followed by } \\
\text { refinements to improve the result }\end{array}$ \\
\hline & $\begin{array}{l}\text { Barret et al., } \\
2011[29]\end{array}$ & $\begin{array}{l}\text { - Full face transplant in a case of a patient with ballistic trauma } \\
\text { to the face }\end{array}$ \\
\hline $\begin{array}{l}\text { Thoracic and } \\
\text { back region }\end{array}$ & $\begin{array}{l}\text { Klink et al., } \\
1994[30]\end{array}$ & $\begin{array}{l}\text { - Muscle flaps (using trapezius and latissimus dorsi muscles) } \\
\text { successfully used for closing complex thoracolumbar wounds }\end{array}$ \\
\hline
\end{tabular}




\begin{tabular}{|c|c|c|}
\hline & & with extensive tissue defects \\
\hline & $\begin{array}{l}\text { Veber et al., } \\
2012[31]\end{array}$ & $\begin{array}{l}\text { - Ballistic chest trauma in a female managed by use of a } \\
\text { musculocutaneous latissimus dorsi pedicled flap for coverage } \\
\text { of soft tissue injuries followed by complex breast } \\
\text { reconstruction }\end{array}$ \\
\hline \multirow[t]{2}{*}{$\begin{array}{l}\text { Abdominal } \\
\text { region }\end{array}$} & $\begin{array}{l}\text { Glezer et al., } \\
1993 \\
{[32]}\end{array}$ & $\begin{array}{l}\text { - Laparotomy, debridement of injured soft tissues and } \\
\text { reconstruction of abdominal wall for severe abdominal injuries }\end{array}$ \\
\hline & $\begin{array}{lll}\text { Paletta et al., } \\
1999 \\
{[33]}\end{array}$ & $\begin{array}{l}\text { - Reconstruction of large abdominal wall defects using } \\
\text { prosthetic mesh and tissue expanders with good outcomes }\end{array}$ \\
\hline \multirow[t]{6}{*}{$\begin{array}{l}\text { Upper } \\
\text { extremity and } \\
\text { hand region }\end{array}$} & $\begin{array}{l}\text { Iselin et al., } \\
1991 \\
{[34]}\end{array}$ & 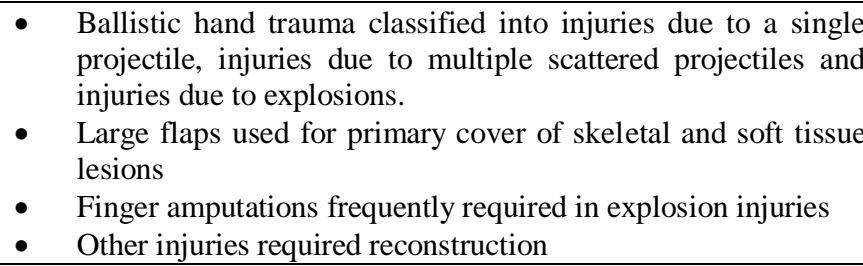 \\
\hline & $\begin{array}{lr}\text { Evans } & \& \\
\text { Luethke, } & 1993 \\
{[35]} & \end{array}$ & $\begin{array}{l}\text { - A latissimus dorsi/scapula combined myo-osseous free flap } \\
\text { used successfully for elbow reconstruction after a shotgun } \\
\text { injury }\end{array}$ \\
\hline & $\begin{array}{l}\text { Lukas et al., } \\
2008[36]\end{array}$ & $\begin{array}{l}\text { - Pedicled and free flaps used to reconstruct soft tissue defects } \\
\text { of hands and forearms with the lateral upper arm flap felt to be } \\
\text { the most suitable flap }\end{array}$ \\
\hline & $\begin{array}{l}\text { Oliveira et al., } \\
2009[37]\end{array}$ & $\begin{array}{l}\text { - Fibula osteoseptocutaneous free flap used to manage upper } \\
\text { extremity ballistic wound with soft tissue and significant bone } \\
\text { loss }\end{array}$ \\
\hline & $\begin{array}{l}\text { Kumar et al., } \\
2009[38]\end{array}$ & $\begin{array}{l}\text { - Upper limb battlefield extremity injuries managed successfully } \\
\text { with fasciocutaneous flaps in } 66 \% \text { of cases, muscle flaps in } \\
19 \% \text { of cases and adipofascial flaps in } 15 \% \text { of cases }\end{array}$ \\
\hline & $\begin{array}{l}\text { Deal et al., } 2011 \\
\text { [39] }\end{array}$ & $\begin{array}{l}\text { - Turnover adipofascial flap used successfully to cover dorsal } \\
\text { hand and finger soft tissue defects }\end{array}$ \\
\hline \multirow{4}{*}{$\begin{array}{l}\text { Lower } \\
\text { extremity, foot } \\
\text { and ankle } \\
\text { region }\end{array}$} & $\begin{array}{l}\text { Redett et al., } \\
2000[40]\end{array}$ & $\begin{array}{l}\text { - Successful lower limb salvage by reconstruction of soft tissue } \\
\text { defects using free gracilis muscle }\end{array}$ \\
\hline & $\begin{array}{lr}\text { Lickstein } \quad \& \\
\text { Bentz, } 2003[41]\end{array}$ & $\begin{array}{l}\text { Complex lower extremity trauma in the paediatric population } \\
\text { managed by skin graft and/or local flap with good outcome }\end{array}$ \\
\hline & $\begin{array}{l}\text { Hasmi, } 2004 \\
{[42]}\end{array}$ & $\begin{array}{l}\text { - Use of free scapular flap for reconstruction of lower extremity } \\
\text { defects }\end{array}$ \\
\hline & $\begin{array}{l}\text { Brown et al., } \\
2009[43]\end{array}$ & $\begin{array}{l}\text { - Early amputation may be required for ballistic mangled } \\
\text { extremity injuries of lower limbs }\end{array}$ \\
\hline
\end{tabular}

\section{DISCUSSION}

\subsection{Pre-hospital management}

At the site of any ballistic injury, the current recommended management is a primary survey of the patient to rapidly identify life-threatening conditions in a well-established ABCDE (A: Airway, B: Breathing, C: Circulation, D: Disability, E: Environment and Exposure) resuscitation sequence as per approved resuscitation guidelines such as ATLS® Advanced Trauma Life Support ${ }^{\circledR}$ guidelines [44]. This should be followed by the prompt transfer of the patient to a trauma centre [8] for more advanced assessment of injuries including the use of imaging techniques followed by appropriate surgical management of the wounds. However in military settings, where haemorrhage from extremity wounds arising from ballistic and blast injuries is a major concern, some authors advocate a modified management sequence proposing that the $\mathrm{ABC}$ sequence of resuscitation be replaced by $\langle\mathrm{C}\rangle \mathrm{ABC}$, where $\langle\mathrm{C}\rangle$ emphasizes the control of catastrophic haemorrhage [45].

\subsection{Initial assessment of the ballistic wound}

During early assessment of an injury caused by a weapon, much consideration was given in the past to the type of weapon used, as to whether it was of a high-velocity or low-velocity type. However the emphasis has now shifted from the nature of the weapon to the nature of the wound. It is currently thought that classifying the ballistic wound into either a high-risk wound or a low-risk wound is more useful clinically [13]. Such classification takes into consideration the type of weapon utilized but also makes use of other variables such as the location of wound, the time to treatment, the path of the projectile, the size of the exit wound, the nature of any organ or bone involvement, the possibility of bullet fragmentation and the number of projectiles present 
thereby providing a more accurate assessment of the injury sustained [13]. This concept serves to emphasize the wound rather than the weapon used and is a better clinical guide to management.

\subsection{Initial management of soft tissue injuries}

Whether ballistic injuries should be managed surgically or conservatively is still a topic for debate. Although it has been common practice to surgically operate on all ballistic wounds, recent literature suggests that some carefully selected wounds could be treated non-operatively by irrigation, dressing and antibiotics [8, 11-14]. Such ballistic wounds selected for non-operative management are ideally low-energy wounds, usually involving limited soft tissue damage. Other small, isolated wounds involving only the skin, subcutaneous tissues and muscle could also be appropriately managed with irrigation, superficial debridement, dressings and antibiotics [14]. Usually direct closure of the wound is not recommended as it is preferable to leave the wound to heal by second intention $[8,11,13-16]$.

On the other hand, wounds which have sustained severe soft tissue damage and contain non-viable tissue have been successfully treated with excision of the wound margins and track, removal of injured subcutaneous fat and fascia, appropriate debridement of devitalized tissues, irrigation and removal of foreign bodies as required [11-16]. Regarding debridement, new recommendations for initial extremity war wound debridement have recently been published [16]. Relevant recommendations include early wound debridement of the extremity to reduce the risk of infection ideally taking place in an operating theatre after appropriate cleansing of the limb. Careful debridement of skin, fat and fascia should be limited to non-viable tissue only. Fasciotomies of muscle compartments may be necessary for to prevent the complications of the compartment syndrome. Muscle should be excised after a careful clinical judgement regarding the viability or non-viability of the muscle based on the traditional clinical evaluation of muscle colour, contractility, consistency and capillary bleeding. The presence of intact or injured nerves, tendons and blood vessels in the debridement zone should be documented. The wounds should normally be irrigated with warmed sterile saline. The use of sterile gauze dressings and negative wound therapy system are both felt to be acceptable options for wound care. Primary closure of the wound is usually recommended to be performed at 4-5 days after a successful debridement; however inspection of the wound in theatre may be necessary earlier at 2 days if traumatised but potentially viable tissue has been noted to be present [16]. Although these guidelines have been proposed for military ballistic wounds, they could also prove useful in civilian settings.

\subsection{Wound contamination and use of antibiotics}

Ballistic wound contamination remains a major concern. Historically, military wound infections were mostly caused by environmental contamination in unhygienic battlefield milieus with delays in the evacuation of the wounded and difficult access to medical treatment, poor sterile techniques, inadequate surgical care of wounds and lack of antibiotics exacerbating the situation. Hence the prevention and treatment of sepsis has long been a priority for careful management [4]. Even in modern days and in civilian settings, wound contamination is an important issue as it has been shown that bacteria could potentially be transferred to the entrance or exit points and within the wound canal by the projectile itself, by clothing or by other exogenous particles $[11,18]$. Recent research also shows that tissues located far from the primary wound cavity could also be potentially contaminated by exogenous particles depending on the nature of the projectile (soft point or full metal jacket bullets) being used [46]. In both civilian and military ballistic wounds, identified factors that contribute to an increased risk of wound infection include the mode of wound injury, the wound site, any delay in wound management, the quality of wound care, the wound size, the viability of tissues, the presence of clothing and other foreign materials, any compromise of local blood supply and the presence of bone or neurovascular injuries $[11,15,47]$. Hence all these factors should be carefully evaluated and taken into consideration in the management protocol.

The benefits of the early use of antibiotics after a ballistic injury have long been a subject of debate. In combat injury, authors of a recent publication recommend the use of intravenous benzyl penicillin only in those injured patients where surgery would be delayed for more than 4 hours [15]. However, recently published updated guidelines [17] for the prevention of infections associated with combat-related injuries recommend the use of systemic antibiotics as soon as possible after injury (within 3 hours) to prevent early infectious complications. Intravenous cefazolin is the main antibiotic recommended for extremity injuries involving skin, soft tissue, and/or bone; additional gram-negative coverage is not felt to be beneficial. Tetanus prophylaxis must also be considered. It must be noted that these are recommendations for military ballistic injuries taking into account the nature of combat injuries. Whether these same recommendations should be applied in a civilian setting remains to be evaluated. In addition it has been reported that wounds caused by secondary blast injuries are potentially contaminated and blast survivors should also receive appropriate antibiotics and tetanus prophylaxis to prevent wound infection [48]. 
Rarely, late infections can occur in ballistic wounds as a result of retained foreign bodies. Such cases have been described in the literature; for instance a case of late infection by methicillin-susceptible Staph. aureus in the neck has been reported seven years after a gunshot injury which had resulted in multiple pellets being embedded in neck tissues [49]. With reference to the guidelines for the prevention of infections in combat-related injuries [17], an intravenous dose of cefazolin is required for isolated retained deep extremity soft tissue metal fragments. Hence antibiotics play an important role in the management of ballistic injuries to prevent both early and late wound infections.

\subsection{Definitive management of soft tissue injuries and reconstruction}

The management of soft tissue injuries after the initial stages of wound care is aimed essentially at restoring both function and aesthetics. Such management usually comprises surgical intervention specific to the nature and location of the soft tissue injury. The use of flaps for the reconstruction of soft tissue injuries is well established. The timing of the reconstruction is a subject for debate. Some authors favour immediate definitive reconstruction within 24 to 48 hours [27] whilst others opt for an early reconstruction within the first 7 days [18, $20,22,24,26,28]$. For injuries of the head and neck, free flap transfers (fasciocutaneous, osteocutaneous or musculocutaneous) for the reconstruction of soft tissue and bony injuries have resulted in good outcomes [18, 20-28]. New treatment modalities are being tried for instance a full face transplant has been used in the management of ballistic injury of the face [29]. Muscle flaps have been used in the thoracic and back regions [30] and complex breast reconstruction has been required in the case of an injured female patient [31]. Ballistic injuries of the abdomen have necessitated the reconstruction of the abdominal wall [32, 33]. Osteocutaneous flaps have been used for upper extremity wounds with significant bone loss [37] whilst fasciocutaneous, adipofascial and muscle flaps have been used in other instances [35, 36, 38, 39]. Lower limb injuries may be often salvaged by the use of local or distant flaps [40-42]. However amputations may be required especially in the case of mangled extremity injuries [43]. Overall the use of flaps in the management of ballistic soft tissue injuries has had good outcomes.

\section{CONCLUSION}

Ballistic injuries in civilians can result from firearms or from blast wounds in survivors. Initial management follows the well established $\mathrm{ABCDE}$ resuscitation sequence although haemorrhage from extremity wounds is of particular concern. The patient should be transferred promptly to an appropriate centre for further management. A careful assessment of the injury should indicate whether it is a high-risk or low-risk wound and this will determine further management. Selected low-risk wounds can be managed conservatively. Other wounds may require exploration, early debridement of devitalized tissues and removal of foreign bodies. Primary closure of wounds is ideally performed at 4-5 days. Relevant recommendations based in military settings regarding initial extremity war wound debridement and the prevention of infections could prove useful in civilian settings. Following early management, definitive reconstruction with the use of flaps is often the treatment of choice.

[1] Richmond TS, Cheney R, Schwab CW. The global burden of non-conflict related firearm mortality. Inj Prev 2005; 11(6): 348352.

[2] Davies MJ, Wells C, Squires PA, Hodgetts TJ, Lecky FE. Civilian firearm injury and death in England and Wales. Emerg Med J 2012; 29(1):10-4.

[3] Home Office. 'Homicides, Firearm Offences and Intimate Violence 2010/11: Supplementary Volume 2 to Crime in England and Wales 2010/11'.

[4] Bellamy RF, Zajtchuk R: The evolution of wound ballistics: a brief history. In: Textbook of Military Medicine, Office of the General Surgeon. Department of the Army. Washington, DC. 1989; 83-106.

[5] Mauffrey C. Management of gunshot wounds to the limbs: A review. The Internet Journal of Orthopedic Surgery 2006; 3(1).

[6] Onuminya JE, Ohwowhiagbese E. Pattern of civilian gunshot injuries in Irrua, Nigeria. S Afr J Surg 2005; 43(4):170-2.

[7] Belmont PJ, Schoenfeld AJ, Goodman G. Epidemiology of combat wounds in Operation Iraqi Freedom and Operation Enduring Freedom: orthopaedic burden of disease. J Surg Orthop Adv 2010; 19(1): 2-7.

[8] Bruner D, Gustafson CG, Visintainer C. Ballistic injuries in the emergency department. Emerg Med Pract 2011 Dec; 13(12): 130.

[9] Rozen N, Dudkiewicz I. Wound ballistics and tissue damage. In: Lerner A, Soudry M Ed, Armed conflict injuries to the extremities. Berlin Heidelberg: Springer-Verlag. 2011; 21-33.

[10] Wang ZG, Feng JX, Liu YQ. Pathomorphological observations of gunshot wounds. Acta Chir Scand Suppl 1982; 508: $185-195$.

[11] Bowyer GW, Rossiter ND. Management of gunshot wounds to the limbs. J Bone Joint Surg Br 1997; 79(6): 1031-6.

[12] Hill PF, Edwards DP, Bowyer GW. Small fragment wounds: biophysics, pathophysiology and principles of management. J R Army Med Corps 2001; 147(1): 41-51.

[13] Volgas DA, Stannard JP, Alonso JE. Current orthopaedic treatment of ballistic injuries. Injury 2005; $36(3)$ : $380-6$.

[14] Lichte P, Oberbeck R, Binnebösel M, Wildenauer R, Pape HC, Kobbe P. A civilian perspective on ballistic trauma and gunshot injuries. Scand J Trauma Resusc Emerg Med 2010; 18: 35.

[15] Eardley WG, Brown KV, Bonner TJ, Green AD, Clasper JC. Infection in conflict wounded. Philos Trans R Soc Lond B Biol Sci $2011 ; 366(1562): 204-18$. 
[16] Guthrie HC, Clasper JC, Kay AR, Parker PJ; Limb Trauma and Wounds Working Groups, ADMST. Initial extremity war wound debridement: a multidisciplinary consensus. J R Army Med Corps 2011; 157(2): 170-5.

[17] Hospenthal DR et al. Guidelines for the prevention of infections associated with combat-related injuries: 2011 update: endorsed by the infectious diseases society of America and the surgical infection society. J Trauma 2011; 71(2 Suppl 2): S210-34.

[18] Gruss JS, Antonyshyn O, Phillips JH. Early definitive bone and soft-tissue reconstruction of major gunshot wounds of the face. Plast Reconstr Surg 1991; 87(3): 436-50.

[19] Shuker S. Management of severe facial injuries by local tissue traction. J Oral Maxillofac Surg 1994; 52(8): 817-20.

[20] Siberchicot F, Pinsolle J, Majoufre C, Ballanger A, Gomez D, Caix P. [Gunshot injuries of the face. Analysis of 165 cases and reevaluation of the primary treatment]. Ann Chir Plast Esthet 1998; 43(2): 132-40. French. Erratum in: Ann Chir Plast Esthet 1998 Jun; 43(3): 286.

[21] Motamedi MH, Behnia H. Experience with regional flaps in the comprehensive treatment of maxillofacial soft-tissue injuries in war victims. J Craniomaxillofac Surg 1999; 27(4): 256-65.

[22] Hollier L, Grantcharova EP, Kattash M. Facial gunshot wounds: a 4-year experience. J Oral Maxillofac Surg 2001; 59(3): 277 82.

[23] Safak T, Akyürek M. Primary one-stage reconstruction of cheek defect after a shotgun blast to the face: use of the latissimus dorsi musculocutaneous free flap for soft-tissue repair and facial reanimation. Ann Plast Surg 2001; 47(4): 438-41.

[24] Motamedi MH. Primary management of maxillofacial hard and soft tissue gunshot and shrapnel injuries. J Oral Maxillofac Surg 2003; 61(12): 1390-8.

[25] Futran ND, Farwell DG, Smith RB, Johnson PE, Funk GF. Definitive management of severe facial trauma utilizing free tissue transfer. Otolaryngol Head Neck Surg 2005; 132(1): 75-85.

[26] Doctor VS, Farwell DG. Gunshot wounds to the head and neck. Curr Opin Otolaryngol Head Neck Surg 2007; 15(4): 213-8.

[27] Kaufman Y, Cole P, Hollier LH Jr. Facial gunshot wounds: trends in management. Craniomaxillofac Trauma Reconstr 2009; 2(2): 85-90.

[28] Danino AM, Hariss PG, Servant JM. Early management, with a minimal initial hospitalization length, of major self-inflicted rifle wounds to the face by a single latissimus dorsi free musculocutaneous flap: a 10-year experience. Eplasty 2009; 9: e23.

[29] Barret JP, Gavaldà J, Bueno J, Nuvials X, Pont T, Masnou N, Colomina MJ, Serracanta J, Arno A, Huguet P, Collado JM, Salamero P, Moreno C, Deulofeu R, Martínez-Ibáñez V. Full face transplant: the first case report. Ann Surg 2011; 254(2): 252-6. Klink BK, Thurman RT, Wittpenn GP, Lauerman WC, Cain JE. Muscle flap closure for salvage of complex back wounds. Spine (Phila Pa 1976) 1994; 19(13): 1467-70

Veber M, Grecea M, Scevola A, Toussoun G, Pauchot J, Delay E. [Complex breast reconstruction after severe chest trauma by firearm]. Ann Chir Plast Esthet 2012; 57(1): 72-8. Epub 2011. French. Glezer JA, Minard G, Croce MA, Fabian TC, Kudsk KA. Shotgun wounds to the abdomen. Am Surg 1993; 59(2): 129-32.

[33] Paletta CE, Huang DB, Dehghan K, Kelly C. The use of tissue expanders in staged abdominal wall reconstruction. Ann Plast Surg 1999; 42(3): 259-65.

[34] Iselin F, Audren JL, Hautefort E, Gouet O, Peze W, Pradet G. [Ballistic hand trauma]. Ann Chir Main Memb Super 1991; 10(5): 437-42. French.

[35] Evans GR, Luethke RW. A latissimus/scapula combined myo-osseous free flap based on the subscapular artery used for elbow reconstruction. Ann Plast Surg 1993; 30(2): 175-9.

[36] Lukas B, Hartl P, Bäcker K. [Soft-tissue reconstruction of the dorsum of the hand and finger to cover the extender tendons]. Handchir Mikrochir Plast Chir 2008; 40(2): 110-4. Review. German.

[37] Oliveira MI, Ferreira PC, Barbosa RF, Horta RJ, Bartosch IM, Reis JC, Amarante JM. Gunshot upper extremity injury reconstructed with a fibula osteoseptocutaneous free flap (case report). Tech Hand Up Extrem Surg 200; 13(2): 60-4.

[38] Kumar AR, Grewal NS, Chung TL, Bradley JP. Lessons from the modern battlefield: successful upper extremity injury reconstruction in the subacute period. J Trauma 2009; 67(4): 752-7.

[39] Deal DN, Barnwell J, Li Z. Soft-tissue coverage of complex dorsal hand and finger defects using the turnover adipofascial flap. J Reconstr Microsurg 2011; 27(2): 133-8.

[40] Redett RJ, Robertson BC, Chang B, Girotto J, Vaughan T. Limb salvage of lower-extremity wounds using free gracilis muscle reconstruction. Plast Reconstr Surg 2000; 106(7): 1507-13.

[41] Lickstein LH, Bentz ML. Reconstruction of pediatric foot and ankle trauma. J Craniofac Surg 2003; 14(4): 559-65.

[42] Hashmi PM. An experience with free scapular flap for reconstruction of lower extremity defects at Aga Khan University Hospital Karachi. J Ayub Med Coll Abbottabad. 2004; 16(1): 54-7.

[43] Brown KV, Ramasamy A, McLeod J, Stapley S, Clasper JC. Predicting the need for early amputation in ballistic mingled extremity injuries. J Trauma 2009; 66(4 Suppl): S93-7.

[44] American College of Surgeons Committee on Trauma. Advanced trauma life support program for doctors, 8th edn. American College of Surgeons, Chicago 2008.

[45] Hodgetts TJ, Mahoney PF, Russell MQ, Byers M. ABC to $<\mathrm{C}>\mathrm{ABC}$ : redefining the military trauma paradigm. Emerg Med J 2006; 23: 745-746.

[46] von See C, Rana M, Stoetzer M, Wilker C, Rücker M, Gellrich NC. A new model for the characterization of infection risk in gunshot injuries: technology, principal consideration and clinical implementation. Head Face Medicine 2011; 7: 18.

[47] Coupland RM. War wounds of bones and external fixation. Injury 1994; 25(4): 211-217.

[48] Born CT. Blast trauma: the fourth weapon of mass destruction. Scand J Surg 2005; 94: 279-285.

[49] Yildiz O, Alp E, Şimşek S, Selçuklu A, Doğanay M. Gunshot wounds and late infection. Turk J Med Sci 2005; 35(4): $269-272$. 